\title{
АВТОР, РЕДАКТОР І ВИДАВЕЦЬ: МИХАЙЛО КОЦЮБИНСЬКИЙ ЯК УПОРЯДНИК ЛІТЕРАТУРНОГО АЛЬМАНАХУ „3 ПОТОКУ ЖИТТЯ” (1905)
}

\author{
ВАДИМ ЛУБЧАК \\ Інститут літератури ім. Т. Г. Шевченка НАН України, Київ - Україна \\ AUTOR, REDAKTOR I WYDAWCA: \\ MYCHAJŁO KOCIUBYNSKI JAKO TWÓRCA ALMANACHU \\ LITERACKIEGO „Z POTOKU ŻYCIA” (1905) \\ WADYM ŁUBCZAK \\ Instytut Literatury im. Tarasa Szewczenki NAN Ukrainy w Kijowie, \\ Kijów - Ukraina
}

STRESZCZENIE. W artykule omawia się udział Mychajła Kociubynskiego w pracach nad almanachami pierwszej dekady XX w. w kontekście jego ogólnej działalności wydawniczej. Dokonano analizy dorobku edytorskiego autora na przykładzie wydanego przez niego almanachu „Z potoku życia” (1905).

AUTHOR, EDITOR AND PUBLISHER:

MYKHAILO KOTSIUBYNSKIY AS A COMPILER OF LITERATURE ALMANAC "FROM THE STREAM OF LIFE"

\section{VADYM LUBCHAK}

Taras Shevchenko Institute of Literature of the NASU, Kyiv - Ukraine.

ABSTRACT. This article reveals M. Kotsybynsky's participation in almanacs of the $10^{\text {ths }}$ of the XIX ${ }^{\text {th }}$ century in the context of his general publishing activity. This article also contains the analysis of the author's heritage as an editor on the material of almanac 'From the Stream of Life' (1905) published by him.

$\mathrm{M}$ ихайло Коцюбинський активно співпрацював з українськими літературними збірниками. На початку ХХ ст. він приходить до масового читача саме завдяки альманахам, зокрема в збірнику „Хвиля за хвилею”, який Борис Грінченко видав у Чернігові 1900 р., вміщено оповідання М. Коцюбинського Для загального добра; Лялечку письменник опублікував у „Дубовому листі”, який разом із Борисом Грінченком та Миколою Чернявським видав у Києві 1903 р. на згадку про Пантелеймона Куліша. У цьому ж році в одеському альманасі „3-над хмар і долин”, який упорядкував та видав Микола Вороний, вийшло оповідання На камені (трохи раніше - 1902 р. — цей твір друкував львівський „Літературно-науковий вісник”); оповідання Поєдинок з'явилося в „Літературному збірнику, зложеному на спомин Олександра Кониського” (1903); новелу Цвіт яблуні М. Коцюбинський опублікував у колективній збірці „На вічну пам’ять Котляревському” (1904), а цикл етюдів „З глибини” подав 
до впорядкованого ним разом із М. Чернявським альманаху „З потоку життя”, що 1905 р. побачив світ у Херсоні. Оповідання ж У грішний світ автор запропонував упорядникам збірника на пошану Ольги Кобилянської ,За красою”, що 1905 р. вийшов друком у Чернівцях.

Крім співпраці з альманахами, М. Коцюбинський був постійним дописувачем до періодичних видань, передовсім йдеться про „Киевскую старину” та „Літературно-науковий вісник”, зокрема в київському виданні автор почав друкувати повість Дорогою иіною, оповідання Fata morgana та ін. Він активно друкувався також і в часописах „Дзвін”, „Зоря”, „Правда”, „Буковина”, „Житє і слово" та ін.

Утім, якщо творчий спадок М. Коцюбинського на сучасному етапі розвитку гуманітарних наук все частіше потрапляє в коло наукових інтересів дослідників (до аналізу творів автора зверталися Н. Калениченко, Т. Гундорова, С. Павличко, Я. Поліщук, Ф. Погребенник, Ю. Кузнєцов та ін.), то його доробок як редактора та упорядника, на нашу думку, й донині залишається недостатньо дослідженим.

Однак М. Коцюбинський увійшов в літературний процес України не лише як самобутній автор, а й один із тих митців, які закликали до оновлення літератури та збагачення художньої форми. I робив він це публічно, намагаючись за допомогою епістолярію та звернень у періодиці спонукати письменників до нової літературної дискусії. А практичним результатом цієї дискусії мав стати вихід окремого літературного альманаху — ,збірника літературних творів різних авторів, часто об'єднаних за певною ознакою (тематичною, жанровою, ідейнохудожньою, територіальною і т. п.)"'.

Загалом ідеєю видати свій альманах, що наочно показав би авторам запит читачів на „нову літературу”, М. Коцюбинський захопився ще наприкінці XIX ст. I цей задум не полишав його, поки не був реалізований виходом збірки ,3 потоку життя".

Більшість укладачів альманахів 1900-х рр. намагалися втілити в збірці певну концепцію. М. Вороний, замислюючи збірник “З-над хмар і долин”, 1901 р. в „Літературно-науковому віснику” закликав українських письменників разом створити альманах, який би ,змістом і виглядом бодай почасти міг наблизитись до новіших течій та напрямів у сучасних літературах європейських"2. Він навіть визначив естетичне кредо альманаху: „Усуваючи на бік різні заспівані тенденції та вимушені моралі, що раз-у-раз зводили наших молодих письменників на стежку шабльону і вузької обмеженості, а також уникаючи творів грубонатуралістичних, брутальних, натомість бажалося б творів хоча б з маленькою ціхою оригінальности, з незалежною свобідною ідеєю, з сучасним змістом; бажалося б творів, де було б хоч трохи філософії, де хоч би клаптик яснів того далекого блакитного неба, що від квітів манить нас своєю неосяжною красою, своєю незглубною таємничістю... На естетичний бік творів має бути вернена найбільша увага"з .

Пізніше Іван Липа в час, коли він був членом „Браття тарасівців”, 1905 р. видав в Одесі альманах „Багаття”. За його концепцією збірник „буде вже не „3-над хмар і долин”, а про землю з усіма їі пекучими проблемами. Бажалося б мати також матеріали й науково-популярні, як-от про літературу, історію, або й публіцистичні"4.

\footnotetext{
${ }^{1}$ Українська літературна енциклопедія, Київ 1988, т. 1 А-Г, с. 50.

2 Літературно-науковий вісник, Львів 1901, т. 16, с. 14.

${ }^{3}$ Там само.

${ }^{4}$ Листи до Михайла Коиюбинського, Чернігів 2002, т. 3, с. 210.
} 
Не стала винятком історія створення М. Коцюбинським та М. Чернявським альманаху „3 потоку життя”.

Ще 1898 р. М. Коцюбинський у листах до українських письменників та видавців наголошував на тому, що Україні потрібен альманах виключно для інтелігенції. Пізніше він розвинув цю думку в „Літературно-науковому віснику". На його переконання, український інтелігент повинен бути не лише читачем, а й об'єктом зображення в літературі. Саме цю ідею він обстоював у листах, адресованих відомим українським письменникам. Фактично ідентичні за змістом листи за підписом упорядників “3 потоку життя” було надіслано до Панаса Мирного, Івана Франка, Ольги Кобилянської, Івана Нечуя-Левицького, Василя Стефаника, Василя Щурата, Івана Липи, Любові Яновської, Михайла Старицького, Осипа Маковей та ін. (оригінали цих листів зберігаються в архіві відділу рукописних фондів та текстології Інституту літератури ім. Т. Г. Шевченка НАН України. Примітно, що, підписані обома упорядниками альманаху, вони однак написані рукою М. Коцюбинського). У зверненні упорядники просили письменників показувати „вірний малюнок різних сторін життя усіх, а не лише якоїсь верстви суспільства”.

„За сто літ існування новіша література наша (з причин, вияснення яких належить до історії) живилась переважно селом, сільським побутом, етнографі$є ю$, - зауважували упорядники в листах письменникам. - Селянин, обставини його життя, його нескладна здебільшого психологія - ото майже й все, над чим працювала фантазія, з чим оперував досі талант українського письменника... Власне, ми маємо на меті видати літературний збірник (поезії, новели, повісті, драматичні твори), в якому хотілось би помістити нові, ніде не надруковані твори, переважно з життя сучасної інтелігенції, а також на теми соціальні, психологічні, історичні і ін." .

На заклик М. Коцюбинського та М. Чернявського відгукнулося чимало відомих авторів, зокрема в збірнику опубліковані такі твори: вірші I. Франка Стріли та Лесі Українки Було се за часів святої Германдади, М. Вороний подав оповідання Пустоцвіт (ним завершується альманах) та цикл віршів “Осокори”, Б. Грінченко — вірш Хвилі, Панас Мирний надіслав переклади з Г. Гайне, a I. Нечуй-Левицький — присвячене М. Лисенкові оповідання Гастролі. О. Кобилянська подала до збірника новелу Iдё̈, а сам М. Коцюбинський опублікував прозовий цикл „3 глибини”, що включає три етюди Хмари, Утома та Самотній.

Отож, в альманасі, що мав на меті продовжити збагачення українського письменства новітніми творами, поряд із модерними працями О. Кобилянської Iдеї, М. Чернявського Низова течія. Із щзоденника, „в якому задекларовані принципи модерністичної літератури на рівні свідомості героя", Л. Яновської Два дні з життя (оповідання, що відкриває альманах), Г. Григоренка Cилует, уміщено роботи, написані в традиційній манері, зокрема оповідання Гастролі I. Нечуя-Левицького, вірші Панаса Мирного та Б. Грінченка.

Реалізувати задум М. Коцюбинський до кінця не зміг, адже, по суті, “не передбачав заперечення „старого”, „студій життя простонародного”, іншими словами, домінуючої традиції, а всього-на-всього хотів розширити іiі рамки".

Я. Поліщук назвав цю „абстрактну, до того ж пом'якшену евфемізмами, програму”, „проектом упровадження національного модернізму”. А м'який стиль заклику авторів працювати з темами „нової літератури” дослідник по-

${ }^{5}$ М. Ко ц юби н с ь ки й, Твори у 6 m., Київ 1961, т. 5. с. 271.

${ }^{6}$ С. П а в л и ч ко, Теорія літератури, Київ 2002, с 111. 
яснює тим, що упорядник „брав до уваги консервативні переконання частини адресатів та хотів уникнути гострої полеміки поміж прихильниками старого та нового стилів"7.

Власне м'який стиль звернення й неготовність частини авторів писати про інтелігенцію й для інтелігенції стали на заваді реалізації поставленої мети.

На думку С. Павличко, „як в всіх попередніх літературних виданнях такого типу, які декларували певний новий „напрям”, такого напряму насправді не виявилося. Збірник репрезентував, по суті, більшість сучасних українських письменників" .

Ще однією проблемою, з якою зіштовхнулися видавці збірника, стала неправильна оцінка свого потенційного читача. „Ініціатори нового альманаху мріяли про такого імпліцитного читача, котрий мав би стати поціновувачем літератури найвищої проби, і цю свою мрію вони проектували на конкретну історичну ситуацію, сподіваючись мобілізувати наявні літературні сили”, - відзначав літературознавець Я. Поліщук' .

I хоча альманах М. Коцюбинського не став видатним мистецьким явищем, він разом із збірником М. Вороного „З-над хмар і долин” призвів до літературної дискусії 1901-1904 pp. i, як результат, став „початком українського модернізму" (С. Павличко).

Привертає увагу той факт, що тогочасна літературна громадськість певною мірою не була готова до нових віянь у традиційному красному письменстві. Як наслідок, далеко не всі письменники привітала ініціативу М. Коцюбинського, зокрема Панас Мирний, висловлюючись про ідею створити альманах із творів про інтелігенцію, зауважував: „Невже то ви геть зовсім зречетеся творів 3 життя селянського, — того життя, що виробило нашу живу мову..."10. Але більшість авторів, яким М. Коцюбинський відправив лист-прохання подати до друку свої твори, відповіли.

Альманах був поданий до цензури 1904 р.; вийшов із друку 1905 р. в Херсоні. У листі до А. Чайковського від 18 травня 1904 р. М. Коцюбинський писав: „Альманах наш, який я назвав „3 потоку життя”, ще з січня лежить у Петербурзькій цензурі. Випустить вона його з своїх пазурів либонь аж восени, а може й на зиму затримає. Надрукую я швидко, аби з цензури дістав"11; а в листі до І. Нечуй-Левицького від 15 грудня 1904 р. повідомляв: „Нещодавно дістав я з цензури свій збірник. Тяжко покалічила його цензура, багато зовсім викинула, та Ваших Гастролів, хвалить бога, не зачепила"12.

Царська цензура, справді, „тяжко покалічила” збірник, по суті, заборонивши упорядникам друкувати найцінніші речі. У спеціальному поданні в Головне управління в справі друку № 2296 від 28 жовтня 1904 р. Санкт-Петербурзький цензурний комітет забороняє друкувати в збірнику низку творів, зокрема Чужий Лесі Українки, До n’ятого коліна Івана Липи, Пенсію Дмитра Марковича та ін. Щодо останнього в доповіді цензора зазначено: „Резкий контраст, проводимый автором между общественною жизнью генерала и бедственным

7 Я. Пол і щу к, I ката, і героя він любив: Михайло Кочюбинський: Літературний портрет, Київ 2010 , с. 96.

${ }^{8} \mathrm{C}$. П а в л и чко, зазнач. джерело, с. 95

9 Я. Пол і щу к , I ката, і героя він любив: Михайло Коиюбинський: Літературний портрет, Київ 2010 , с. 96.

${ }^{10}$ Літературно-науковий..., с. 356.

${ }^{11}$ М.Коц ю б и н с ь к и й, Твори в 7 m., Київ 1974, т. 5. с. 313.

${ }^{12}$ Там само, с. 322. 
положением солдата, стремление его убедить читателя в том, что простой люд даже в том случае, когда он имеет право на внимание к себе правительства, оставляется им в полной беспомощности, делают, по мнению и. д. цензора, появление этой повести в свет невозможным"13.

„3 потоку життя” - не перший редакторський досвід М. Коцюбинського. Ще під час укладання альманаху „Дубове листя” (1903), присвяченого П. Кулішу, в підходах до редагованих текстів повною мірою виявилась його творча індивідуальність. „Разом втрьох ми взялися за роботу, - згадував М. Чернявський. - I тут я зразу почув різницю між Грінченком і Коцюбинським, як взагалі щодо розуміння й оцінки творів і письменників, так, головним чином, щодо ïx мови. М. Коцюбинського принаджувала в творах їх, так би мовити, екзотичність, часом штучність, взагалі те, що здавалося йому новим та оригінальним. Грінченкові більше подобались твори, вільні від штучності, він любив писання реальне, правдиве й доступне широким масам. Щодо мови, Коцюбинський був прихильником мови західноукраїнської й частково галицької, а Грінченко, навпаки... Але деякі з галицьких рукописів і Грінченко, і я зрікалися читати через їх мову. Тоді читав Коцюбинський і читав часом з замилуванням і захопленням, і ліричним навіть підйомом"14.

Однак головний альманах М. Коцюбинського „3 потоку життя”, на який він покладав неабиякі сподівання як у творчому, так і у фінансовому сенсі, дива не створив. Зі своєю прогресивною за своєю суттю ідеєю збірника „нової літератури" упорядники запізнилися. На початку XX ст. пожвавлення літературного життя відбилося в появі багатьох альманахів та декламаторів, а після 1905 р., коли ліквідували заборону української мови, почала відроджуватися й українська преса. У вирі революційних подій, коли серед українців панували піднесені настрої, дітище М. Коцюбинського просто загубилося серед нових збірників, брошур, книг та газет.

Розуміли це й самі видавці „3 потоку життя”. У листі від 28 березня 1910 р. (через 5 років після виходу альманаху) М. Чернявський писав М. Коцюбинському: “ < ..> Злощасний альманах наш викинутий з потоку життя, ніяк не попаде в його, і я досі маю клопіт 3 друкарнею. Оце обіщав цим літом виплатити борг, заробивши грошей на приватній роботі... I цей альманах, i „Перша ластівка” (херсонський збірник молодих авторів, виданий М. Чернявським у 1905 р. В. Л.) каменем лягли на полиці книгарень і на мою душу. Ну, та якось я їх скину!"15.

Утім, завдання, які ставив М. Коцюбинський перед собою та молодим поколінням українських письменників (Лесею Українкою, О. Кобилянською, В. Стефаником, М. Чернявським, М. Вороним та ін.), які на зламі століття виступали із новими поглядами на основні теоретико-естетичні постулати, до певної міри реалізувати таки вдалося. Помітну роль у цьому відіграв херсонський альманах „3 потоку життя”, що, хоч і не сповна, все-таки продемонстрував орієнтир української літератури на естетичні цінності новітньої європейської літератури.

${ }^{13}$ М. Коц ю б и н с ь к и й, Царська цензура про альманах „, 3 потоку життя”, [в:] Відділ рукописних фондів та текстології Інституту літератури ім. Т. Г. Шевченка НАН України, ф. 7, спр. 600 , арк. 5.

${ }^{14}$ М. Че рн я в с ьки й, Кедр Ливана: Спогади про Б. Грінченка, Херсон 1920, с. 22-23.

15 Листи до Михайла Коиююбнського в 4 m., Київ-Ніжин 2003, т. 4, с. 293. 